\title{
Definitions of "respiratory depression" with intrathecal morphine postoperative analgesia: a review of the literature
}

\author{
[Définitions de la "dépression respiratoire” de l'analgésie postopératoire réalisée \\ avec de la morphine intrathécale : une revue documentaire]
}

Samuel Ko BSc PHM, David H. Goldstein MSc FRCPC, Elizabeth G. VanDenKerkhof DrPH

Purpose: To review the postoperative intrathecal morphine (ITM) analgesia literature for their definitions of "respiratory depression" (RD).

Source: Medline (1966 - June Week 5 200I) and reference lists were searched for original studies involving bolus-dose ITM for postoperative analgesia, which used "respiratory depression" or similar terms.

Principal findings: The search identified 209 studies. These were included if ITM use was appropriate (bolus dose, postoperative analgesia) and the term "respiratory depression" was used, which left 96 studies remaining. Forty-four (46\%) did not define "RD" despite using this term. A further 24 (25\%) defined RD with respiratory rate (RR) alone. Only 28 (29\%) defined RD with more than $\mathrm{RR}$ alone. There was no statistically significant association between the presence of a definition for RD with study design, study size or publication period. Also, no significant association existed between rigorousness of RD definitions and the above factors.

Conclusion: The term "respiratory depression" has no clear definition from a review of the literature on ITM use for postoperative analgesia. While defining RD with bradypnea is superior to having no definition, this is still inadequate. In future research, the consistent use of terms with specific meanings will facilitate understanding the true incidence of ITM's respiratory effects. If "respiratory depression" is used, then an explicit definition of its meaning should be provided. Future research must also address what is clinically significant respiratory impairment from intrathecal opioids, and how to optimally monitor for this. Further delineating their risks vs benefits will allow for more optimal dosing.
Objectif : Passer en revue les documents sur l'analgésie postopératoire, réalisée avec la morphine intrathécale (MIT), quant à leurs définitions de la "dépression respiratoire" (DR).

Source : La base Medline (1966 - Semaine 5, juin 200 I) et les listes de lectures de référence ont été fouillées à la recherche d'études originales sur des bolus de MIT administrés comme analgésie postopératoire, et dans lesquelles on retrouve le terme "dépression respiratoire" ou des termes similaires.

Constatations principales : La recherche nous a fourni 209 études. Les études (96) comportant un usage approprié de la MIT (dose en bolus, analgésie postopératoire) et l'utilisation du terme "dépression respiratoire" ont été retenues. Malgré l'utilisation du terme "DR", 44 études (46\%) ne la définissaient pas. D'autres études, 24 (25\%), n'utilisaient que le terme "fréquence respiratoire" (FR) pour définir la DR. Seulement 28 (29\%) études en donnaient une définition plus large. II n'y avait pas d'association significative entre la présence d'une définition de la DR et le devis de l'étude, sa taille ou sa date de publication. Aussi, aucune association significative n'a été trouvée entre la rigueur des définitions de la DR et les facteurs susmentionnés.

Conclusion : Le terme "dépression respiratoire" n'a pas de définition claire dans les documents examinés sur l'usage de la MIT comme analgésie postopératoire. II est préférable de définir la DR par la bradypnée que de ne pas la définir, mais cela demeure incomplet. À l'avenir, l'usage uniforme de termes et de leurs définitions spécifiques facilitera la compréhension de la véritable incidence des effets respiratoires de la MIT. Le terme "dépression respiratoire" doit être accompagné d'une définition explicite. Les recherches à venir doivent traiter des affections respiratoires cliniques significatives causées par les opioïdes intrathécaux et de la façon de les déceler le plus efficacement. En déterminant davantage leurs risques et leurs bienfaits, nous pourrons en établir une posologie optimale.

From the Department of Anesthesiology, Queen's University, Kingston, Ontario, Canada.

Address correspondence to: Dr. David H. Goldstein, Department of Anesthesiology, Queen's University, 76 Stuart Street, Kingston,

Ontario K7L 2V7, Canada. Phone: 613-548-7827; Fax: 613-548-1375; E-mail: goldsted@kgh.kari.net

Grants: MRC (CIHR) Summer Studentship (Samuel Ko).

Accepted for publication September 30, 2002.

Revision accepted April 25, 2003. 


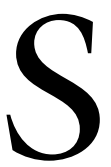

PINAL administrations of opioids offer segmental analgesia, ${ }^{1}$ but have side effects including pruritus, nausea and vomiting, urinary retention, hypotension, and importantly, "respiratory depression" (RD), both early and delayed. ${ }^{2-5}$

Intrathecal morphine (ITM) was the opioid involved in many of the cases of delayed $\mathrm{RD},{ }^{6-8}$ a serious but rare complication. ITM produces a dose-related analgesia and $\mathrm{RD}^{2-4,9-14}$ via separate receptor mechanisms. ${ }^{15}$ Peak RD with ITM occurs between 3.5 to $12 \mathrm{hr}$ postinjection. $3,4,8,9,11,16,17$ Large surveys report the incidence of $\mathrm{RD}$ after ITM ranging from $0.03 \%{ }^{18}$ up to $7 \% .^{7}$ Some believe ITM is underused for routine postoperative analgesia ${ }^{19}$ due to the risk of delayed RD.

Despite its severity, the term "respiratory depression" was inconsistently defined amongst studies. ${ }^{20}$ Quite commonly, there was no definition whatsoever, despite the use of this term. ${ }^{21,22}$ Definitions of $\mathrm{RD}$ in postoperative ITM analgesia literature included: a low respiratory rate $(\mathrm{RR}){ }^{23}$ high arterial $\mathrm{PCO}_{2}$ values ${ }^{24}$ low oxyhemoglobin saturation with pulse oximetry $\left(\mathrm{SpO}_{2}\right){ }^{25}$ increased level of sedation (LOS), ${ }^{26}$ depressed ventilatory response to hypoxia and hypercarbia, ${ }^{27}$ the need for naloxone treatment, ${ }^{7}$ or a combination of these. However, the lack of a more specific or uniform definition of RD makes it difficult to ascertain its true incidence. Statistics gathered from large retrospective studies and surveys are also difficult to interpret due to under-reporting from recall bias. ${ }^{7}$

Our objective was to review the postoperative ITM analgesia literature and examine their definitions of $\mathrm{RD}$.

\section{Methods}

\section{Systematic search}

Medline (1966 - June Week 5 2001) was searched by the primary author for original studies (no case reports or letters) involving bolus-dose ITM for postoperative analgesia, which used "respiratory depression" or similar terms. "RD" was in the context of central RD, not from other etiologies such as neuromuscular disease.

Different search strategies were employed to include studies with the following Medical Subject Headings (MeSHs) in the title or abstract: "injections, spinal", "anesthesia, spinal", and "morphine", along with key words in the title or abstract: "intrathecal morphine", "subarachnoid morphine", "spinal morphine", and "subdural morphine". Only studies involving adult humans published in English were included. Additional reports were found through reference list searches.

Studies were excluded with the following MeSHs: "neoplasms", "palliative care", "pain, intractable", "long-term care", "infusion pumps", "labour", "case report", "child", or "adolescent" and the following key words: "chronic pain", "cancer", "labour pain", or "labour". Unpublished trials and abstracts were excluded, as were reports on criteria for extubation. ${ }^{21,28,29}$

\section{Data extraction and analysis}

For each included study, year of publication, type of surgery, number of patients enrolled (including numbers after withdrawals), whether study design was both a double-blinded and randomized controlled trial (DBRCT), ITM dose, and definition (if any) of "respiratory depression" were tabulated by the primary author (Table A, available as "additional material" at www.cjajca.org). The definitions of $\mathrm{RD}$ were categorized as undefined (UND), a definition with RR alone (RRA), and a definition with other than RR alone (ORRA) [Table I]. Study data were entered into a Microsoft Excel spreadsheet.

Data analysis was performed using EpiInfo 2000 (version 1.1, Center for Disease Control, Atlanta, GA, USA). We attempted to identify associated factors with having an explicit definition of RD. We postulated that DB-RCTs, larger, or more recent studies would be more likely to define $\mathrm{RD}$, and perhaps be more rigorous in that definition. Publication period and sample size were not normally distributed; therefore each variable was made into a binary variable. Selection of cut-off points was based primarily on maintaining approximately equitable distribution across categories. Publication period was dichotomized into approximate ten-year intervals (1980-1990 or 1991-2001) while study size was divided

TABLE I Definitions of respiratory depression

\begin{tabular}{|c|c|c|c|}
\hline Definition & Studies (n) & $\%$ of total & Comments \\
\hline Undefined (UND) & 44 & 46 & \\
\hline RR Alone (RRA) & 24 & 25 & \\
\hline \multicolumn{4}{|l|}{ Other than RRA (ORRA) } \\
\hline $\mathrm{RR}$ and/or $\mathrm{O}_{2}$ saturation * & 6 & 6 & \\
\hline $\mathrm{RR}$ with $\mathrm{O}_{2}$ saturation* & & & \\
\hline and Cyanosis & 2 & 2 & \\
\hline $\mathrm{RR}$ and/or ABGs & 6 & 6 & \\
\hline ABGs alone & 3 & 3 & \\
\hline Naloxone treatment & 3 & 3 & All surveys \\
\hline RR with LOS & 2 & 2 & \\
\hline $\mathrm{CO}_{2}$ stimulation alone & 2 & 2 & \\
\hline RR with $\mathrm{CO}_{2}$ stimulation & 1 & 1 & \\
\hline Multiple factors & 2 & 2 & \\
\hline Statistical & 1 & 1 & $\begin{array}{l}\text { ANOVA of } \\
\mathrm{RR} \text { and } \\
\mathrm{PaCO}_{2}\end{array}$ \\
\hline Total & 96 & 100 & \\
\hline
\end{tabular}

* $\mathrm{O}_{2}$ saturation includes $\mathrm{SpO}_{2}$ and $\mathrm{SaO}_{2}$. $\mathrm{RR}=$ respiratory rate; $\mathrm{ABG}=$ arterial blood gas; $\mathrm{LOS}=$ level of sedation. 
TABLE II Presence of definitions according to different study variables

\begin{tabular}{|c|c|c|c|c|c|c|}
\hline Study variable & $n$ & $\begin{array}{l}R D \\
\text { Defined }\end{array}$ & $\%$ & $\begin{array}{l}\text { Risk ratio } \\
(95 \% \text { CI) }\end{array}$ & $\chi^{2}$ & P-value \\
\hline \multicolumn{7}{|l|}{$D B-R C T$} \\
\hline $\mathrm{No}^{*}$ & 38 & 18 & 47 & 1.0 & & \\
\hline Yes & 58 & 34 & 59 & $1.2(0.8-1.8)$ & 1.2 & 0.28 \\
\hline \multicolumn{7}{|l|}{ Size } \\
\hline$<50^{*}$ & 48 & 22 & 46 & 1.0 & & \\
\hline$\geq 50$ & 48 & 30 & 63 & $1.4(0.9-2.0)$ & 2.7 & 0.10 \\
\hline \multicolumn{7}{|c|}{ Publication year } \\
\hline $1980-1990$ & 33 & 19 & 58 & 1.0 & & \\
\hline 1991-2001 & 63 & 33 & 52 & $0.9(0.6-1.3)$ & 0.2 & 0.63 \\
\hline
\end{tabular}

$\mathrm{RD}=$ respiratory depression; DB-RCT $=$ double-blinded, randomized controlled trial; * Referent category.

TABLE III Definitions of respiratory depression in double-blinded, randomized controlled trials

\begin{tabular}{lllllll}
\hline Definition & $n$ & DB-RCT & $\%$ & $\begin{array}{l}\text { Risk ratio } \\
(95 \% \text { CI })\end{array}$ & $\chi^{2}$ & P-value \\
\hline UND $^{*}$ & 44 & 24 & 55 & 1.0 & & \\
RRA & 24 & 16 & 67 & $1.2(0.8-1.8)$ & 0.9 & 0.33 \\
ORRA & 28 & 18 & 64 & $1.2(0.8-1.7)$ & 0.66 & 0.42 \\
\hline
\end{tabular}

$\mathrm{UND}=$ respiratory depression undefined; RRA = respiratory rate alone as definition; ORRA $=$ other than respiratory rate alone as definition; DB-RCT = double-blinded, randomized controlled trial; * Referent category.

TABLE IV Definitions of respiratory depression according to study size

\begin{tabular}{llllllll}
\hline Definition & $n$ & Study size $\geq$ & $\%$ & $\begin{array}{c}\text { Risk ratio } \\
(95 \% \text { CI })\end{array}$ & $\chi^{2}$ & P-palue \\
\hline UND $^{*}$ & 44 & 18 & 41 & 1.0 & & \\
RRA & 24 & 13 & 54 & $1.3(0.8-2.2)$ & 1.08 & 0.30 \\
ORRA & 28 & 17 & 61 & $1.5(0.9-2.4)$ & 2.65 & 0.10 \\
\hline
\end{tabular}

$\mathrm{UND}=$ no definition of respiratory depression; RRA = respiratory rate alone as definition; ORRA = other definition than respiratory rate alone; *Referent category.

TABLE V DEFINITIONS OF RESPIRATORY DEPRESSION ACCORDING TO PUBLICATION PERIOD

\begin{tabular}{lllllll}
\hline Definition & $n$ & Year $>1990$ & $\%$ & $\begin{array}{c}\text { Risk ratio } \\
(95 \% \text { CI })\end{array}$ & $\chi^{2}$ & P-value \\
\hline UND $^{*}$ & 44 & 30 & 68 & 1.0 & & \\
RRA & 24 & 17 & 71 & $1.0(0.8-1.4)$ & 0.05 & 0.82 \\
ORRA & 28 & 16 & 57 & $0.8(0.6-1.2)$ & 0.89 & 0.34 \\
\hline
\end{tabular}

$\mathrm{UND}=$ no definition of respiratory depression; RRA = respiratory rate alone as definition; ORRA = other definition than respiratory rate alone.

into studies with less than 50 or greater than 49 patients. Making the assumption that DB-RCTs are higher order studies and therefore more rigorous in design, study design was also dichotomized by whether or not studies were DB-RCTs. The association between publication period, study size and study design with the presence or absence of any definition of RD was assessed (Table II). The association between these same factors with a spe- cific definition of RD (UND, RRA or ORRA) was also assessed (Tables III-V). Chi square and $P$-values were calculated to assess the probability of obtaining a specific outcome, while risk ratios and 95\% confidence intervals were calculated to obtain an estimate of the magnitude and precision of the frequency of the outcome. An alpha of 0.05 and a power of $80 \%$ were used to assess for statistical significance. 


\section{Results}

Systematic search

The original Medline search and hand-searching identified 209 studies. These were included if ITM use was appropriate (bolus dose, for postoperative analgesia) and the term "respiratory depression" was used. Some studies from the Medline search did not use "RD" in the text ${ }^{30-34}$ and were thus excluded. Eventually, 96 studies were included for analysis $7,8,10-14,17,18,20-29,35-111$ (Table A available online).

The search found that the earliest year of publication amongst these 96 studies was $1981.1^{12,13,44}$ This was not surprising, as the earliest published report of ITM was made in $1979 .{ }^{1}$ Thirty-three studies $(34 \%)$ were published between 1980 and 1990, while 63 $(66 \%)$ were published between 1991 and 2001 . Fortyeight of 96 studies $(50 \%)$ involved at least 50 subjects. Fifty-eight of $96(60 \%)$ were DB-RCT studies. There were five large-scale surveys $7,17,18,42,74$ which were not considered part of this group. No case-controlled studies were found.

\section{Data analysis}

From the 96 studies of ITM for postoperative analgesia, 44 (46\%) did not define "respiratory depression" (UND) despite using this term (Table I). Twentythree of the 44 undefined studies made objective measurements, such as arterial blood gases (ABGs), but were considered UND, as specific levels were not provided. ${ }^{12,13,28,46,52,58,60,63,65,68,72,77,82,83,86,90,91,95,96,99,101,10}$ 5,107 A further 24 studies (25\%) defined RD with RRA. Less than one-third of the studies, 28 (29\%), defined RD with ORRA. The majority of this latter group defined $R D$ with $R R$ in conjunction with other variables, such as $\mathrm{SpO}_{2}$ and ABGs. Six studies defined RD with both $\mathrm{RR}$ and $\mathrm{ABGs},{ }^{8,14,20,74,103,109}$ while three used ABGs alone. ${ }^{24,56,78} \mathrm{RR}$ was the most common variable used to define RD.

Oxygen saturation in conjunction with $\mathrm{RR}$ defined $\mathrm{RD}$ in six studies. ${ }^{25,51,64,75,88,102}$ Most of these studies used pulse oximetry, though Lauretti et al. ambiguously measured "oxygen saturations". ${ }^{88} \mathrm{SpO}_{2}$ values ranging from " $\leq 85 \% " 25$ to $" \leq 94 \% " 51$ were used in the definitions. Two other studies included presence of cyanosis, $\mathrm{RR}$ and either oxyhemoglobin saturation from $\mathrm{SpO}_{2}{ }^{37}$ or $\mathrm{ABG}$ analysis ${ }^{38}$ in their definitions.

Three large surveys defined $\mathrm{RD}$ by the use of naloxone treatment. ${ }^{7,17,18}$ Rawal et al. ${ }^{17}$ defined RD for their extradural group differently from their ITM group and conceded to having an "inexact" definition of $\mathrm{RD}$ in another survey. ${ }^{18}$ More specific definitions were not stated, even though the surveys asked respondents for specific criteria to define ventilatory depression. ${ }^{17}$
There also exist less common definitions of RD. These include statistical analyses of respiratory variables, ${ }^{10} \mathrm{RR}$ with $\mathrm{LOS},{ }^{26,59}$ and specific radiographic and/or laboratory abnormalities. ${ }^{61}$ Johnson et al. defined $\mathrm{RD}$ with multiple criteria, including $\mathrm{RR}$, $\mathrm{PaCO}_{2}$, drowsiness, naloxone treatment and respiratory failure. ${ }^{81}$ Ventilatory responses to hypercarbia alone ${ }^{11,27}$ or along with $\mathrm{RR}^{36}$ were used as research methods to define RD.

Many studies that did not define RD (UND) still assessed respiratory variables. For instance, Bernard et $a l .{ }^{46}$ compared occurrences of " $\mathrm{RR}<10$ " and " $\mathrm{SpO}_{2}$ $<90 \%$ ", but defined RD by hypercapnia and requirement for naloxone. Hypercapnic $\mathrm{PaCO}_{2}$ levels were undefined, although naloxone was given if $\mathrm{PaCO}_{2}>$ $50 \mathrm{mmHg}$. Undefined studies also assessed $\mathrm{RR},{ }^{22,60}$ level of sedation, ${ }^{58} \mathrm{SpO}_{2},{ }^{65} \mathrm{ABGs},{ }^{107}$ end-tidal $\mathrm{PCO}_{2},{ }^{13}$ presence of cyanosis, ${ }^{83}$ apnea ${ }^{12}$ and/or hypopnea. ${ }^{54}$ Similarly, studies that defined RD may have additionally monitored $\mathrm{SpO}_{2},{ }^{67,104} \mathrm{RR}^{24}$ and pulmonary function test (PFT) values ${ }^{20}$ without using it in their definition. The reader should not infer that these measures define RD.

The frequency of $\mathrm{RD}$ being defined was similar between DB-RCT studies and non-DB-RCT studies (Table II); (risk ratio 1.2, 95\% confidence intervals [CI] 0.8-1.8). The frequency of having any definition of $\mathrm{RD}$ included in the study was not significantly associated with study size (risk ratio $1.4,95 \%$ CI $0.9-2.0$ ). Finally, publication period (1980 - 1990 or 1991 2001) was also not associated with the inclusion of any definition of RD (risk ratio $0.9,95 \%$ CI $0.6-1.3$ ). When definitions of RD were divided into three categories (UND, RRA and ORRA) and the risk ratios calculated for DB-RCT design, study size and publication period (Tables III-V), the results remained statistically insignificant. Thus, rigorousness of RD definitions was not associated with study design, study size or publication period; however, small sample sizes also contributed to non-significant findings.

\section{Discussion}

This literature review found that almost half of studies which suggested postoperative ITM caused "respiratory depression" did not define this term. This is a worrisome observation. Surprisingly, increased prevalence of $\mathrm{RD}$ being defined was not associated with more recent publication periods. This latter result is of particular interest, given the advent of initiatives like the CONSORT Statement. ${ }^{112}$

While it is recognized that $\mathrm{RD}$ is a serious complication associated with ITM, the true incidence of RD remains unclear for several reasons. One reason is that 
$\mathrm{RD}$ is a rare event, influenced by a large number of variables, which therefore requires a large number of patients to define this incidence. ${ }^{102}$ Rare events are traditionally studied with case-control studies. However, no case-control studies were identified in the literature. Also, opioid-induced RD is confounded by hypoventilation and hypoxemia from midazolam sedation, general anesthesia and surgery itself. ${ }^{4}$ Some studies used iv patient-controlled analgesia after ITM, ${ }^{36,37}$ which may also confound ITM-induced $\mathrm{RD}$. Importantly, "respiratory depression" is not a term with a clear or standard definition. Therefore, studies quoting events of RD may actually be observing different phenomena. An attempt to standardize this definition would reduce inter-observer variability and promote understanding the true incidence of the respiratory side effects with ITM.

A quarter of the studies in our review defined $\mathrm{RD}$ with only RR assessment. Many defined RD with a RR less than $10 .{ }^{40}$ This method is simple, non-invasive, and the patient is not inconvenienced. ${ }^{104}$ While defining $\mathrm{RD}$ with bradypnea is superior to no definition whatsoever, it is considered to be an inadequate index of ventilatory depression. $4,10,15,27,81,113-115$ RR does not necessarily correlate with ITM dose, hypoxemia or depressed ventilatory response to $\mathrm{CO}_{2}$-stimulation. ${ }^{9,27}$ Patients may even be hypoxemic ${ }^{4}$ or hypercapnic with a normal RR. ${ }^{8,24,81,83,116,117}$ Conversely, patients with low RRs may compensate adequately to keep $\mathrm{PaCO}_{2}$ levels within normal limits. ${ }^{10}$ Since RR is not a reliable indicator of $\mathrm{RD}$, studies using RR to evaluate RD may be underreporting the true incidence. RR may even be a poor indicator of impending apnea. ${ }^{114}$ Therefore, we believe that RR should not be used alone to define RD.

$\mathrm{RD}$ has also been defined as a failure to respond adequately to hypercapnia or hypoxia. ${ }^{118}$ This may be considered a "standard" definition of RD. Central RD exists when the respiratory neurons of the medulla fail to respond appropriately to these stimuli. Respiratory neurons also exist in other brainstem areas. Normally, the dominant control of ventilation is mediated through an increase in $\mathrm{PaCO}_{2}$, which strongly stimulates central chemoreceptors, ${ }^{119}$ leading to increased ventilation. RD from morphine is characterized by a dose-related, naloxone-reversible depression of resting minute ventilation (Ve) with proportional reduction of tidal volume $(\mathrm{Vt}),{ }^{120-122}$ decreased $\mathrm{PaO}_{2}$ and $\mathrm{pH}$, increased $\mathrm{PaCO}_{2},{ }^{121,123}$ and decreased ventilatory drive stimulated by hypercapnia and hypoxia. ${ }^{124,125}$ In volunteers, ITM caused a dose-related depression of medullary respiratory centre sensitivity to ventilatory stimulus. ${ }^{9}$ Decreased chemosensitivity of the respiratory centres to hypercapnia is a sensitive index of RD. ${ }^{113,126}$
Ten studies defined RD with ABG values (either alone, with $\mathrm{RR}$, or as part of multiple criteria). There are many advantages in defining $\mathrm{RD}$ with $\mathrm{ABGs}$. It offers the best measurement of ventilatory adequacy, directly and quantitatively ${ }^{127}$ reflecting the net results of gas exchange. ABGs are universally used in pulmonary function assessment. ${ }^{128}$ With ITM, there is a dose and timerelated increase in $\mathrm{PaCO}_{2}$. and decrease in $\mathrm{pH} .{ }^{9}$ While there are no absolute levels of $\mathrm{PaO}_{2}$ or $\mathrm{PaCO}_{2}$ that indicate $\mathrm{RD}$ or failure, generally in those without preexisting lung disease, $\mathrm{PaO}_{2}$ less than $60 \mathrm{mmHg}$ (hypoxemia) or $\mathrm{PaCO}_{2}$ more than $50 \mathrm{mmHg}$ (hypercarbia) were used. ${ }^{8,129}$ Disadvantages of using ABGs include its invasiveness, time delay for results, intermittent frequency, and possible lack of correlation with ventilatory response to hypercapnia and hypoxemia. ${ }^{27}$ Since invasiveness is a concern, its use should be minimized where possible.

Clinically, hypercapnia appears to provide the most rigorous definition of "respiratory depression", as RD has been defined classically as "a failure to respond adequately, on a moment-to-moment basis, to hypercapnia or hypoxia". ${ }^{118}$ However, the most practical and effective method for detecting hypoxemia and/or hypoventilation after ITM is unknown., ${ }^{5,104}$ Perhaps the term "respiratory depression" should only be used for experimental situations, when there is a depressed ventilatory response to hypercapnia or hypoxemia. Then, a low RR would be better referred to as "bradypnea" and not "respiratory depression". Similarly, a low $\mathrm{SpO}_{2}$ would be preferably termed "hypoxemia".

\section{Conclusion}

The term "respiratory depression" has no clear definition from a review of the literature involving ITM for postoperative analgesia. Approximately half of these studies did not even define the term, despite using it. This makes it difficult to ascertain the true respiratory risks of this technique. The inclusion of any definition of "respiratory depression" was not associated with DBRCT, sample sizes of greater than 49 subjects or publication after 1990. The rigorousness of RD definitions was also not associated with these study variables.

In future research, the consistent use of terms with specific meanings, as opposed to the ambiguous catchall term "respiratory depression", will facilitate understanding the true incidence of ITM's respiratory effects. If "respiratory depression" is used, then an explicit definition of its meaning should be clearly provided. Future research must also address what is clinically significant respiratory impairment from intrathecal opioids, and how to optimally monitor for these effects. Further delineating their risks $v s$ benefits will allow for more optimal dosing determinations. 


\section{References}

1 Wang JK, Nauss LA, Thomas JE. Pain relief by intrathecally applied morphine in man. Anesthesiology 1979; 50: 149-51.

2 Chaney MA. Side effects of intrathecal and epidural opioids. Can J Anaesth 1995; 42: 891-903.

3 Cousins MJ, Mather LE. Intrathecal and epidural administration of opioids. Anesthesiology 1984; 61: 276-310.

4 Etches RC, Sandler AN, Daley MD. Respiratory depression and spinal opioids. Can J Anaesth 1989; 36: 165-85.

5 Morgan $M$. The rational use of intrathecal and extradural opioids. Br J Anaesth 1989; 63: 165-88.

6 Davies GK, Tolhurst-Cleaver CL, James TL. Respiratory depression after intrathecal narcotics. Anaesthesia 1980; 35: 1080-3.

7 Gustafsson LL, Schildt B, Jacobsen K. Adverse effects of extradural and intrathecal opiates: report of a nationwide survey in Sweden. Br J Anaesth 1982; 54: 479-86.

8 Jacobson L, Chabal C, Brody MC. A dose-response study of intrathecal morphine: efficacy, duration, optimal dose, and side effects. Anesth Analg 1988; 67: 1082-8.

9 Bailey PL, Rhondeau S, Schafer PG, et al. Doseresponse pharmacology of intrathecal morphine in human volunteers. Anesthesiology 1993; 79: 49-59.

10 Boezaart AP, Eksteen JA, Spuy GV, Rossouw P, Knipe $M$. Intrathecal morphine. Double-blind evaluation of optimal dosage for analgesia after major lumbar spinal surgery. Spine 1999; 24: 1131-7.

11 Clergue F, Montembault C, Despierres O, Ghesquiere F, Harari A, Viars $P$. Respiratory effects of intrathecal morphine after upper abdominal surgery. Anesthesiology 1984; 61: 677-85.

12 Gjessing J, Tomlin PJ. Postoperative pain control with intrathecal morphine. Anaesthesia 1981; 36: 268-76.

13 Samii K, Chauvin M, Viars P. Postoperative spinal analgesia with morphine. Br J Anaesth 1981; 53: 817-20.

14 Yamaguchi $H$, Watanabe S, Motokawa K, Ishizawa $\Upsilon$. Intrathecal morphine dose-response data for pain relief after cholecystectomy. Anesth Analg 1990; 70: 168-71.

15 Shook JE, Watkins WD, Camporesi EM. Differential roles of opioid receptors in respiration, respiratory disease, and opiate-induced respiratory depression. Am Rev Respir Dis 1990; 142: 895-909.

16 Jones RD, Jones JG. Intrathecal morphine: naloxone reverses respiratory depression but not analgesia. $\mathrm{Br}$ Med J 1980; 281: 645-6.

17 Rawal N, Arner S, Gustafsson LL, Allvin R. Present state of extradural and intrathecal opioid analgesia in Sweden. A nationwide follow-up survey. Br J Anaesth 1987; 59: 791-9.

18 Rawal N, Allvin R. Epidural and intrathecal opioids for postoperative pain management in Europe-a 17nation questionnaire study of selected hospitals. Euro Pain Study Group on Acute Pain. Acta Anaesthesiol Scand 1996; 40: 1119-26.

19 Stoelting $R K$. Intrathecal morphine-an underused combination for postoperative pain management. Anesth Analg 1989; 68: 707-9.

20 Nilsson E, Perttunen K, Kalso E. Intrathecal morphine for post-sternotomy pain in patients with myasthenia gravis: effects on respiratory function. Acta Anaesthesiol Scand 1997; 41: 549-56.

21 Chaney MA, Furry PA, Fluder EM, Slogoff S. Intrathecal morphine for coronary artery bypass grafting and early extubation. Anesth Analg 1997; 84: 241-8.

22 Charuluxananan S, Somboonviboon W, Kyokong $O$, Nimcharoendee $K$. Ondansetron for treatment of intrathecal morphine-induced pruritus after cesarean delivery. Reg Anesth Pain Med 2000; 25: 535-9.

23 Grace D, Bunting H, Milligan KR, Fee JP.

Postoperative analgesia after co-administration of clonidine and morphine by the intrathecal route in patients undergoing hip replacement. Anesth Analg 1995; 80: 86-91.

24 Jacobson L, Chabal C, Brody MC, Ward RJ, Ireton $R C$. Intrathecal methadone and morphine for postoperative analgesia: a comparison of the efficacy, duration, and side effects. Anesthesiology 1989; 70: 742-6.

25 Abouleish E, Rawal N, Rashad MN. The addition of $0.2 \mathrm{mg}$ subarachnoid morphine to hyperbaric bupivacaine for cesarean delivery: a prospective study of 856 cases. Reg Anesth 1991; 16: 137-40.

26 Grace D, Fee JP. A comparison of intrathecal morphine-6-glucuronide and intrathecal morphine sulfate as analgesics for total hip replacement. Anesth Analg 1996; 83: 1055-9.

27 Johnson A, Bengtsson M, Soderlind K, Lofstrom JB. Influence of intrathecal morphine and naloxone intervention on postoperative ventilatory regulation in elderly patients. Acta Anaesthesiol Scand 1992; 36: 436-44.

28 Zarate E, Latham P, White PF, et al. Fast-track cardiac anesthesia: use of remifentanil combined with intrathecal morphine as an alternative to sufentanil during desflurane anesthesia. Anesth Analg 2000; 91: 283-7.

29 Chaney MA, Nikolov MP, Blakeman BP, Bakhos M. Intrathecal morphine for coronary artery bypass graft 
procedure and early extubation revisited. J Cardiothorac Vasc Anesth 1999; 13: 574-8.

30 Blacklock JB, Rea GL, Maxwell RE. Intrathecal morphine during lumbar spine operation for postoperative pain control. Neurosurgery 1986; 18: 341-4.

31 Mayson KV, Gofton EA, Chambers KG. Premedication with low dose oral clonidine does not enhance postoperative analgesia of intrathecal morphine. Can J Anesth 2000; 47: 752-7.

32 Thorn SE, Wattwil M, Lindberg G, Sawe J. Systemic and central effects of morphine on gastroduodenal motility. Acta Anaesthesiol Scand 1996; 40: 177-86.

33 Cohen E, Neustein SM. Intrathecal morphine during thoracotomy, Part I: Effect on intraoperative enflurane requirements. J Cardiothorac Vasc Anesth 1993; 7: 154-6.

34 Tuominen $M$, Valli $H$, Kalso E, Rosenberg $P H$. Efficacy of $0.3 \mathrm{mg}$ morphine intrathecally in preventing tourniquet pain during spinal anaesthesia with hyperbaric bupivacaine. Acta Anaesthesiol Scand 1988; 32: 113-6.

35 Abboud TK, Lee K, Zhu J, et al. Prophylactic oral naltrexone with intrathecal morphine for cesarean section: effects on adverse reactions and analgesia. Anesth Analg 1990; 71: 367-70.

36 Abboud TK, Dror A, Mosaad P, et al. Mini-dose intrathecal morphine for the relief of post-cesarean section pain: safety, efficacy, and ventilatory responses to carbon dioxide. Anesth Analg 1988; 67: 137-43.

37 Abouleish E, Rawal N, Fallon K, Hernandez D. Combined intrathecal morphine and bupivacaine for cesarean section. Anesth Analg 1988; 67: 370-4.

38 Abouleish E, Rawal N, Tobon-Randall B, et al. A clinical and laboratory study to compare the addition of $0.2 \mathrm{mg}$ of morphine, $0.2 \mathrm{mg}$ of epinephrine, or their combination to hyperbaric bupivacaine for spinal anesthesia in cesarean section. Anesth Analg 1993; 77: 457-62.

39 Alhashemi JA, Sharpe MD, Harris CL, Sherman V, Boyd D. Effect of subarachnoid morphine administration on extubation time after coronary artery bypass graft surgery. J Cardiothorac Vasc Anesth 2000; 14: 639-44.

40 Alhashemi JA, Crosby ET, Grodecki W, Duffy PJ, Hull $K A$, Gallant $C$. Treatment of intrathecal morphineinduced pruritus following caesarean section. Can J Anaesth 1997; 44: 1060-5.

41 Amanor-Boadu SD. Assessment of minidose intrathecal morphine for analgesia after haemorroidectomy. West Afr J Med 1992; 11: 146-9.

42 Arner S, Rawal N, Gustafsson LL. Clinical experience of long-term treatment with epidural and intrathecal opioids-a nationwide survey. Acta Anaesthesiol Scand
1988; 32: 253-9.

43 Aun C, Thomas D, St. John-Jones L, Colvin MP, Savege $T M$, Lewis CT. Intrathecal morphine in cardiac surgery. Eur J Anaesthesiol 1985; 2: 419-26.

44 Barron DW, Strong JE. Postoperative analgesia in major orthopaedic surgery. Epidural and intrathecal opiates. Anaesthesia 1981; 36: 937-41.

45 Bengtsson M, Lofstrom JB, Merits $H$. Postoperative pain relief with intrathecal morphine after major hip surgery. Reg Anesth 1983; 8: 139-43.

46 Bernard JM, Hommeril JL, Legendre MP, Passuti N, Pinaud M. Spinal or systemic analgesia after extensive spinal surgery: comparison between intrathecal morphine and intravenous fentanyl plus clonidine. J Clin Anesth 1993; 5: 231-6.

47 Cardoso MM, Carvalho JC, Amaro AR, Prado AA, Cappelli EL. Small doses of intrathecal morphine combined with systemic diclofenac for postoperative pain control after cesarean delivery. Anesth Analg 1998; 86: 538-41.

48 Chadwick HS, Ready LB. Intrathecal and epidural morphine sulfate for postcesarean analgesia-a clinical comparison. Anesthesiology 1988; 68: 925-9.

49 Chaney MA, Smith KR, Barclay JC, Slogoff S. Largedose intrathecal morphine for coronary artery bypass grafting. Anesth Analg 1996; 83: 215-22.

50 Chung CJ, Kim JS, Park HS, Chin YJ. The efficacy of intrathecal neostigmine, intrathecal morphine, and their combination for post-cesarean section analgesia. Anesth Analg 1998; 87: 341-6.

51 Chung JH, Sinatra RS, Sevarino FB, Fermo L. Subarachnoid meperidine-morphine combination. An effective perioperative analgesic adjunct for cesarean delivery. Reg Anesth 1997; 22: 119-24.

52 Cohen SE, Subak LL, Brose WG, Halpern J. Analgesia after cesarean delivery: patient evaluations and costs of five opioid techniques. Reg Anesth 1991; 16: 141-9.

53 Colbert S, O'Hanlon DM, Galvin S, Chambers F, Moriarty DC. The effect of rectal diclofenac on pruritus in patients receiving intrathecal morphine. Anaesthesia 1999; 54: 948-52.

54 Cole PJ, Craske DA, Wheatley RG. Efficacy and respiratory effects of low-dose spinal morphine for postoperative analgesia following knee arthroplasty. Br J Anaesth 2000; 85: 233-7.

55 Culebras X, Gaggero G, Zatloukal J, Kern C, Marti $R A$. Advantages of intrathecal nalbuphine, compared with intrathecal morphine, after cesarean delivery: an evaluation of postoperative analgesia and adverse effects. Anesth Analg 2000; 91: 601-5.

56 Cunningham AJ, McKenna JA, Skene DS. Single injection spinal anaesthesia with amethocaine and 
morphine for transurethral prostatectomy. $\mathrm{Br} \mathrm{J}$ Anaesth 1983; 55: 423-7.

57 Davis I. Intrathecal morphine in aortic aneurysm surgery. Anaesthesia 1987; 42: 491-7.

58 Dennis AR, Leeson-Payne CG, Hobbs GJ. Analgesia after caesarean section. The use of rectal diclofenac as an adjunct to spinal morphine. Anaesthesia 1995; 50: 297-9.

59 Domsky M, Kwartowitz J. Efficacy of subarachnoid morphine in a community hospital. Reg Anesth 1992; 17: 279-82.

60 Downing R, Davis I, Black J, Windsor CW. When do patients given intrathecal morphine need postoperative systemic opiates? Ann R Coll Surg Engl 1985; 67: 251-3.

61 Drakeford MK, Pettine KA, Brookshire L, Ebert F. Spinal narcotics for postoperative analgesia in total joint arthroplasty. A prospective study. J Bone Joint Surg Am 1991; 73: 424-8.

62 Fitzpatrick GJ, Moriarty DC. Intrathecal morphine in the management of pain following cardiac surgery. A comparison with morphine i.v. Br J Anaesth 1988; 60: 639-44.

63 Fogarty DJ, O'Hanlon JJ, Milligan KR.

Intramuscular ketorolac following total hip replacement with spinal anaesthesia and intrathecal morphine. Acta Anaesthesiol Scand 1995; 39: 191-4.

64 Fogarty DJ, Milligan KR. Postoperative analgesia following total hip replacement: a comparison of intrathecal morphine and diamorphine. J R Soc Med 1995; 88: 70-2.

65 Fogarty DJ, Carabine UA, Milligan KR. Comparison of the analgesic effects of intrathecal clonidine and intrathecal morphine after spinal anaesthesia in patients undergoing total hip replacement. $\mathrm{Br} \mathrm{J}$ Anaesth 1993; 71: 661-4.

66 Fournier R, Van Gessel E, Macksay M, Gamulin Z. Onset and offset of intrathecal morphine versus nalbuphine for postoperative pain relief after total hip replacement. Acta Anaesthesiol Scand 2000; 44: 940-5.

67 France JC, Jorgenson SS, Lowe TG, Dwyer AP. The use of intrathecal morphine for analgesia after posterolateral lumbar fusion. A prospective, double-blind, randomized study. Spine 1997; 22: 2272-7.

68 Gerancher JC, Floyd H, Eisenach J. Determination of an effective dose of intrathecal morphine for pain relief after cesarean delivery. Anesth Analg 1999; 88: 346-51.

69 Goyagi T, Nishikawa T. Oral clonidine premedication enhances the quality of postoperative analgesia by intrathecal morphine. Anesth Analg 1996; 82: 1192-6.
70 Goyagi T, Nishikawa T. The addition of epinephrine enhances postoperative analgesia by intrathecal morphine. Anesth Analg 1995; 81: 508-13.

71 Grace D, Milligan KR, Morrow BJ, Fee JP. Coadministration of pethidine and clonidine: a spinal anaesthetic technique for total hip replacement. $\mathrm{Br} \mathrm{J}$ Anaesth 1994; 73: 628-33.

72 Gray JR, Fromme GA, Nauss LA, Wang JK, Ilstrup $D M$. Intrathecal morphine for post-thoracotomy pain. Anesth Analg 1986; 65: 873-6.

73 Gwirtz KH, Kim HC, Nagy DJ, et al. Intravenous ketorolac and subarachnoid opioid analgesia in the management of acute postoperative pain. Reg Anesth 1995; 20: 395-401.

74 Gwirtz KH, Young JV, Byers RS, et al. The safety and efficacy of intrathecal opioid analgesia for acute postoperative pain: seven years' experience with 5969 surgical patients at Indiana University Hospital. Anesth Analg 1999; 88: 599-604.

75 Holmstrom B, Laugaland K, Rawal N, Hallberg $S$. Combined spinal epidural block versus spinal and epidural block for orthopaedic surgery. Can J Anaesth 1993; 40: 601-6.

76 Huang HJ, Ishimaru T, Yamabe T. Intrathecal morphine for postoperative pain relief. Asia Oceania J Obstet Gynaecol 1984; 10: 197-204.

77 Husaini SW, Russell IF. Intrathecal diamorphine compared with morphine for postoperative analgesia after caesarean section under spinal anaesthesia. Br J Anaesth 1998; 81: 135-9.

78 Jacobson L, Chabal C, Brody MC, Ward RJ, Wasse L. Intrathecal methadone: a dose-response study and comparison with intrathecal morphine $0.5 \mathrm{mg}$. Pain 1990; 43: 141-8.

79 Jiang CJ, Liu CC, Wu TJ, et al. Mini-dose intrathecal morphine for post-cesarean section analgesia. Ma Zui Xue Za Zhi 1991; 29: 683-9.

80 Johnson A, Bengtsson M, Merits H, Lofstrom JB. Anesthesia for major hip surgery. A clinical study of spinal and general anesthesia in 244 patients. Reg Anesth 1986; 11: 83-8.

81 Johnson A, Bengtsson M, Lofstrom JB, Rane A, Wahlstrom $A$. Influence of postoperative naloxone infusion on respiration and pain relief after intrathecal morpine. Reg Anesth 1988; 13: 146-51.

82 Johnson RG, Miller M, Murphy M. Intraspinal narcotic analgesia. A comparison of two methods of postoperative pain relief. Spine 1989; 14: 363-6.

83 Kalso E. Effects of intrathecal morphine, injected with bupivacaine, on pain after orthopaedic surgery. Br J Anaesth 1983; 55: 415-22.

84 Kirson LE, Goldman JM, Slover RB. Low-dose intrathecal morphine for postoperative pain control in 
patients undergoing transurethral resection of the prostate. Anesthesiology 1989; 71: 192-5.

85 Klamt JG, Slullitel A, Garcia IV, Prado WA. Postoperative analgesic effect of intrathecal neostigmine and its influence on spinal anaesthesia. Anaesthesia 1997; 52: 547-51.

86 Knudsen K, Lisander B. Metoclopramide decreases emesis after spinal anesthesia supplemented with subarachnoid morphine. Reg Anesth 1994; 19: 390-4.

87 Latham P, Zarate E, White PF, et al. Fast-track cardiac anesthesia: a comparison of remifentanil plus intrathecal morphine with sufentanil in a desfluranebased anesthetic. J Cardiothorac Vasc Anesth 2000; 14: 645-51.

88 Lauretti GR, Reis MP, Prado WA, Klamt JG. Doseresponse study of intrathecal morphine versus intrathecal neostigmine, their combination, or placebo for postoperative analgesia in patients undergoing anterior and posterior vaginoplasty. Anesth Analg 1996; 82: 1182-7.

89 Licina MG, Schubert A, Tobin JE, Nicodemus HF, Spitzer $L$. Intrathecal morphine does not reduce minimum alveolar concentration of halothane in humans: results of a double-blind study. Anesthesiology 1991; 74: 660-3.

90 Liu $M$, Rock P, Grass JA, et al. Double-blind randomized evaluation of intercostal nerve blocks as an adjuvant to subarachnoid administered morphine for post-thoracotomy analgesia. Reg Anesth 1995; 20: 418-25.

91 Liu N, Kublman G, Dalibon N, Moutafis M, Levron $J C$, Fischler $M$. A randomized, double-blinded comparison of intrathecal morphine, sufentanil and their combination versus iv morphine patient-controlled analgesia for postthoracotomy pain. Anesth Analg 2001; 92: 31-6.

92 Lydon AM, Cooke T, Duggan F, Shorten GD. Delayed postoperative gastric emptying following intrathecal morphine and intrathecal bupivacaine. Can J Anesth 1999; 46: 544-9.

93 Moore RA, Paterson GM, Bullingham RE, Allen MC, Baldwin D, McQuay HJ. Controlled comparison of intrathecal cinchocaine with intrathecal cinchocaine and morphine. Clinical effects and plasma morphine concentrations. Br J Anaesth 1984; 56: 837-41.

94 Motamed C, Bouaziz H, Franco D, Benhamou D. Analgesic effect of low-dose intrathecal morphine and bupivacaine in laparoscopic cholecystectomy. Anaesthesia 2000; 55: 118-24.

$95 \mathrm{Nag} S$, Gode GR. Comparative evaluation of subarachnoid morphine \& pethidine for post-operative analgesia. Indian J Med Res 1984; 79: 818-23.

96 Neustein SM, Cohen E. Intrathecal morphine during thoracotomy, Part II: effect on postoperative meperidine requirements and pulmonary function tests. J Cardiothorac Vasc Anesth 1993; 7: 157-9.

97 Niemi L, Pitkanen MT, Tuominen MK, Rosenberg $P H$. Comparison of intrathecal fentanyl infusion with intrathecal morphine infusion or bolus for postoperative pain relief after hip arthroplasty. Anesth Analg 1993; 77: 126-30.

$98 O^{\prime}$ Neill P, Knickenberg C, Bogahalanda S, Booth AE. Use of intrathecal morphine for postoperative pain relief following lumbar spine surgery. J Neurosurg 1985; 63: 413-6.

99 Paech MJ. The influence of adrenaline on postoperative analgesia after subarachnoid morphine. Anaesth Intensive Care 1993; 21: 79-84.

100 Pavy TJ, Gambling DR, Merrick PM, Douglas MJ. Rectal indomethacin potentiates spinal morphine analgesia after caesarean delivery. Anaesth Intensive Care 1995; 23: 555-9.

101 Ross DA, Drasner K, Weinstein PR, Flaherty JF, Barbaro NM. Use of intrathecally administered morphine in the treatment of postoperative pain after lumbar spinal surgery: a prospective, double-blind, placebo-controlled study. Neurosurgery 1991; 28: 700-4.

102 Sarma VJ, Bostrom UV. Intrathecal morphine for the relief of post-hysterectomy pain-a double-blind, doseresponse study. Acta Anaesthesiol Scand 1993; 37: 223-7.

103 Slappendel R, Weber EW, Dirksen R, Gielen MJ, van Limbeek J. Optimization of the dose of intrathecal morphine in total hip surgery: a dose-finding study. Anesth Analg 1999; 88: 822-6.

104 Swart M, Sewell J, Thomas D. Intrathecal morphine for caesarean section: an assessment of pain relief, satisfaction and side-effects. Anaesthesia 1997; 52: 373-7.

105 Swenson JD, Hullander RM, Wingler K, Leivers D. Early extubation after cardiac surgery using combined intrathecal sufentanil and morphine. J Cardiothorac Vasc Anesth 1994; 8: 509-14.

106 Taylor A, Healy M, McCarroll M, Moriarty DC. Intrathecal morphine: one year's experience in cardiac surgical patients. J Cardiothorac Vasc Anesth 1996; 10: 225-8.

107 Vanstrum GS, Bjornson KM, Ilko R. Postoperative effects of intrathecal morphine in coronary artery bypass surgery. Anesth Analg 1988; 67: 261-7.

108 Wetmore RW, Kalt MA, Sybert JW, Hecker ET. Intrathecal administration of morphine followed by patient-controlled intravenous administration for postoperative analgesia. Clin Pharm 1992; 11 : 958-61. 
109 ramaguchi H, Watanabe S, Fukuda T, Takabashi $H$, Motokawa K, Ishizawa $\Upsilon$. Minimal effective dose of intrathecal morphine for pain relief following transabdominal hysterectomy. Anesth Analg 1989; 68: 537-40.

110 rang T, Breen TW, Archer D, Fick G. Comparison of $0.25 \mathrm{mg}$ and $0.1 \mathrm{mg}$ intrathecal morphine for analgesia after cesarean section. Can J Anesth 1999; 46: 856-60.

111 Yokota $T$, Uehara $K$, Nomoto $\Upsilon$. Intrathecal morphine suppresses NK cell activity following abdominal surgery. Can J Anesth 2000; 47: 303-8.

112 Moher D, Schulz KF, Altman DG. The CONSORT statement: revised recommendations for improving the quality of reports of parallel-group randomised trials. J Am Podiatr Med Assoc 2001; 91: 437-42.

113 Varrassi $G$, Celleno D, Capogna $G$, et al. Ventilatory effects of subarachnoid fentanyl in the elderly. Anaesthesia 1992; 47: 558-62.

114 Camporesi EM, Nielsen CH, Bromage PR, Durant $P A$. Ventilatory $\mathrm{CO}_{2}$ sensitivity after intravenous and epidural morphine in volunteers. Anesth Analg 1983; 62: 633-40.

115 Rawal N, Wattwil M. Respiratory depression after epidural morphine-an experimental and clinical study. Anesth Analg 1984; 63: 8-14.

116 Ready LB, Oden R, Chadwick HS, et al. Development of an anesthesiology-based postoperative pain management service. Anesthesiology 1988; 68: 100-6.

117 Stenseth R, Sellevold O, Breivik H. Epidural morphine for postoperative pain: experience with 1085 patients. Acta Anaesthesiol Scand 1985; 29: 148-56.

118 Nunn JF. Applied Respiratory Physiology: from Cell to Systems, 3rd ed. Cambridge: Butterworth \& Co.; 1987: 379-82.

119 Sherwood L. Human Physiology, 2nd ed. St. Paul: West Publishing Co.; 1993: 453.

120 Dripps RD, Comroe JH. Clinical studies on morphine I. The immediate effect of morphine administered intravenously and intramuscularly upon the respiration of normal man. Anesthesiology 1946; 6: 462-8.

121 Nagashima H, Karamanian A, Malovany R, et al. Respiratory and circulatory effects of intravenous butorphanol and morphine. Clin Pharmacol Ther 1976; 19: 738-45.

122 Gal TJ, DiFazio CA, Moscicki J. Analgesic and respiratory depressant activity of nalbuphine: a comparison with morphine. Anesthesiology 1982; 57: 367-74.

123 Popio KA, Jackson DH, Ross AM, Schreiner BF, $\Upsilon_{u}$ $P N$. Hemodynamic and respiratory effects of morphine and butorphanol. Clin Pharmacol Ther 1978; 23: 281-7.

124 Weil JV, McCullough RE, Kline JS, Sodal IE.
Diminished ventilatory response to hypoxia and hypercapnia after morphine in normal man. $\mathrm{N}$ Engl J Med 1975; 292: 1103-6.

125 Romagnoli A, Keats AS. Ceiling effect for respiratory depression by nalbuphine. Clin Pharmacol Ther 1980; 27: 478-85.

126 Nunn JF. Applied Respiratory Physiology, 3rd ed. Cambridge: Butterworth \& Co.; 1987: 97-9.

127 Polk SL, Faria RW, Hill CH, Marota JJ, Schneider $A J L$. Anesthesiology. In: Lawrence PF (Ed.). Essentials of Surgical Specialties, 2nd ed. Philadelphia: Lippincott Williams \& Wilkins; 2000: $1-67$.

128 Androgue HJ, Tobin MJ. Respiratory Failure. Cambridge: Blackwell Science Inc.; 1997.

129 West JB. Pulmonary Pathophysiology-the Essentials, 4th ed. Baltimore: Williams \& Wilkins; 1992. 